\title{
A comprehensive numerical design of firefighting systems for onshore petroleum installations
}

\author{
Iqrash Shafiq*, Murid Hussain*, ${ }^{*}$, Sumeer Shafique*, Muhammad Haris Hamayun*, \\ Muhammad Mudassir $^{* *}$, Zeeshan Nawaz ${ }^{* * *}$, Ashfaq Ahmed ${ }^{* * * *,+}$, and Young-Kwon Park ${ }^{* * *,+}$ \\ *Department of Chemical Engineering, COMSATS University Islamabad, Lahore Campus, \\ M.A. Jinnah Building, Defence Road, Off Raiwind Road, Lahore, Pakistan \\ **Process Engineering Department, Saudi Basic Industries Corporation (SABIC), Riyadh, Kingdom of Saudi Arabia \\ ***SABIC Technology \& Innovation, Saudi Basic Industries Corporation (SABIC), Riyadh, Kingdom of Saudi Arabia \\ $* * * *$ School of Environmental Engineering, University of Seoul, Seoul 02504, Korea \\ (Received 3 February 2021 • Revised 31 March 2021 • Accepted 23 April 2021)
}

\begin{abstract}
Petroleum facilities containing welded steel bulk flammable liquid product storage tanks possess sundry fire hazards inherent to the facility. These installations urgently require indigenous efficient firefighting systems. So, the efficient design of firewater and firefighting foam system is dynamic in controlling fire-related emergencies. The paper deals with the in-depth conceptualization of the design and analysis of firefighting systems for a typical petroleum handling, processing and storage facility in compliance with international standards. The study is aimed to formulate the elementary technique for designing an optimized firefighting system. The proposed objective was achieved by considering an ideal tank farm site that is most commonly located in a range of terminal stations, pumping stations, petroleum refineries, well sites, etc. Sufficient illumination was enumerated on the standardized classification of the liquid fuel product with respect their flammability range. Special guidelines regarding firefighting system design basis were defined and an optimized firefighting and foam system design was developed. Moreover, sufficient limitations that must be considered during the firefighting of huge tank fires are discussed. This comprehensive numerical design philosophy offers a simple and wide-ranging guide to industrial practitioners by formulating the principles for industrial firefighting system design.
\end{abstract}

Keywords: Fire, Explosion, Firewater, Firefighting Foam, Design Philosophy, Petroleum Storage Tanks

\section{INTRODUCTION}

Petroleum exploration, production, storage, processing, and transportation facilities are among the key installations of any country. Petroleum product storage tanks are a vital component of any petroleum refinery and any of the associated terminal installations. These large-capacity storage facilities are proven to be not only the most important element in the continuous development of the oil and gas industry but also referred to as the lifelines to the nation [1].

Fire hazard is among the utmost communal catastrophes globally, endangering asset protection and human safety. Fires and explosions are inevitable in bulk petroleum storage facilities. These incidents result in extensive property losses, expert manpower causalities and adverse impact on surroundings. Literature shows numerous single and multiple tank fire accidents resulting in very unpleasant consequences [2-5].

Owing to the coronavirus global pandemic during 2020, the demand for petroleum products drastically declined to result in

\footnotetext{
${ }^{\dagger}$ To whom correspondence should be addressed.

E-mail: drmhussain@cuilahore.edu.pk,drahmed85@uos.ac.kr, catalica@uos.ac.kr

Copyright by The Korean Institute of Chemical Engineers.
}

the topping up of all petroleum storage tanks globally approaching zero ullage issues [6]. The unavailability of sufficient storage facility forced the refining industry to shut down their plants and wait for petroleum products' upliftment to ensure adequate ullage for plant rundowns [7]. The said emergency turned down the petroleum refining industries to enhance the storage capacity of their respective tank farms and other associated terminal storage depots in addition to the rapid growth of other hazardous chemical industries [8-10]. The race towards maximizing the capacity comprised of high capital incentives may proceed towards the creation of safety-critical firefighting system design-related issues [11].

International organizations such as NFPA, API, and SFPE have structured sufficient guidelines for the designing, construction, and safe operation of these hazardous petroleum handling facilities [1214]. The said guidelines are very complicated and tricky so that the engineering, procurement and construction contractors working on the designing, construction and commissioning of these hazardous facilities take advantage of misinterpretation to save huge costs, consequently compromising the integrity of fire safety installation systems. In addition to these international guidelines, many countries have structured their own simple, concise and to-the-point guidelines [15-17]. Nevertheless, the compromise towards these safety-critical firefighting systems is still observed globally [19].

The reliability, efficiency and user-friendliness of the firefighting 
system is a mandatory requirement in parallel with the installation of bulk petroleum storage tanks to ensure property, manpower and environmental protection. To facilitate industrial practitioners and fill this knowledge gap, this study aims to structure the designing steps in a simplified manner and carefully select the base parameters for the numerical design of the firefighting system for tank farms of a petroleum storage facility. The model specimen con- taining petroleum storage tanks, firewater injection, storage, distribution and application system alongside the firefighting foam storage, distribution and application system is considered and designing capacities such as firewater tank storage requirement, firewater pump flowrate requirement, firewater distribution header sizing, nature and number of firefighting equipment required per tank, number of nozzle requirement, foam storage requirement, number of foam

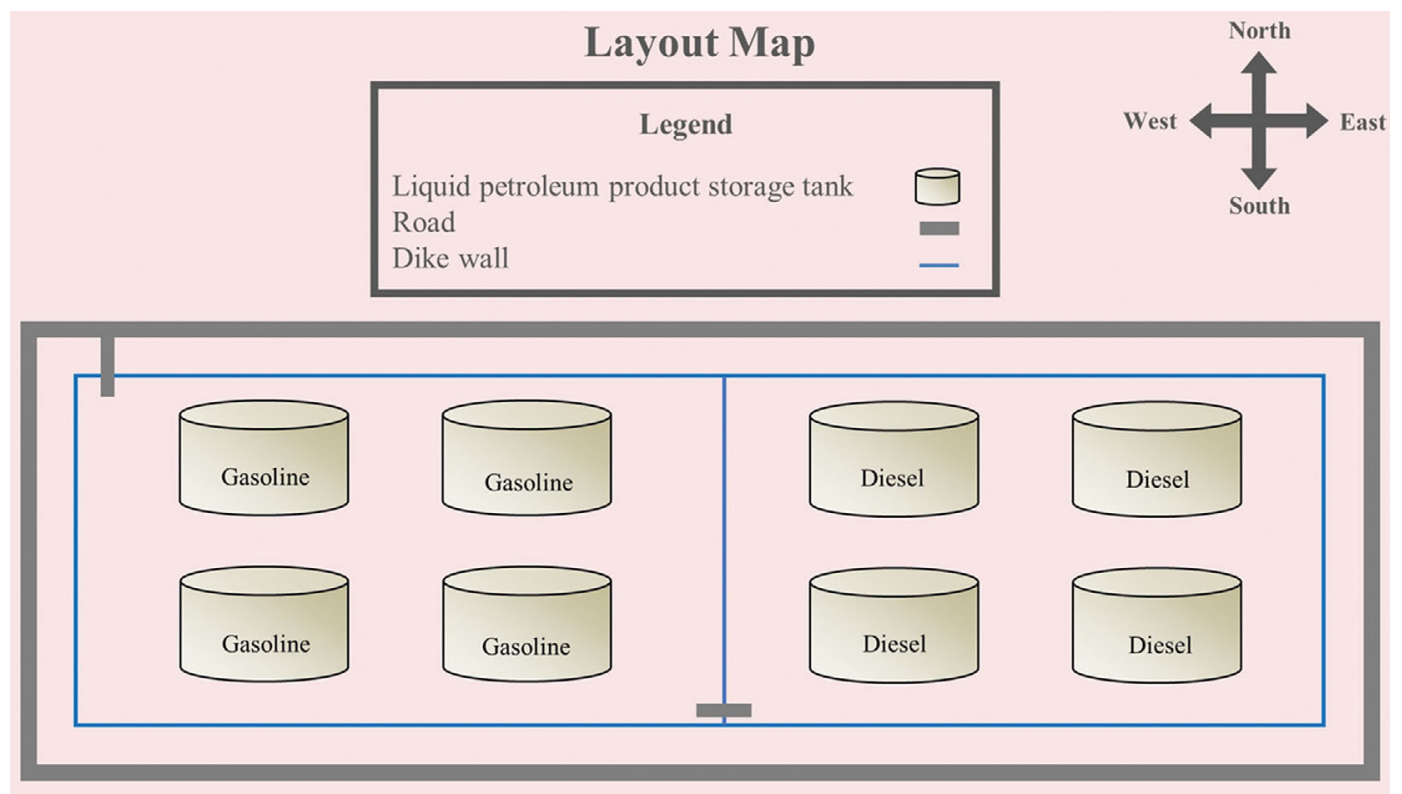

Fig. 1. Model layout of the tank farm.

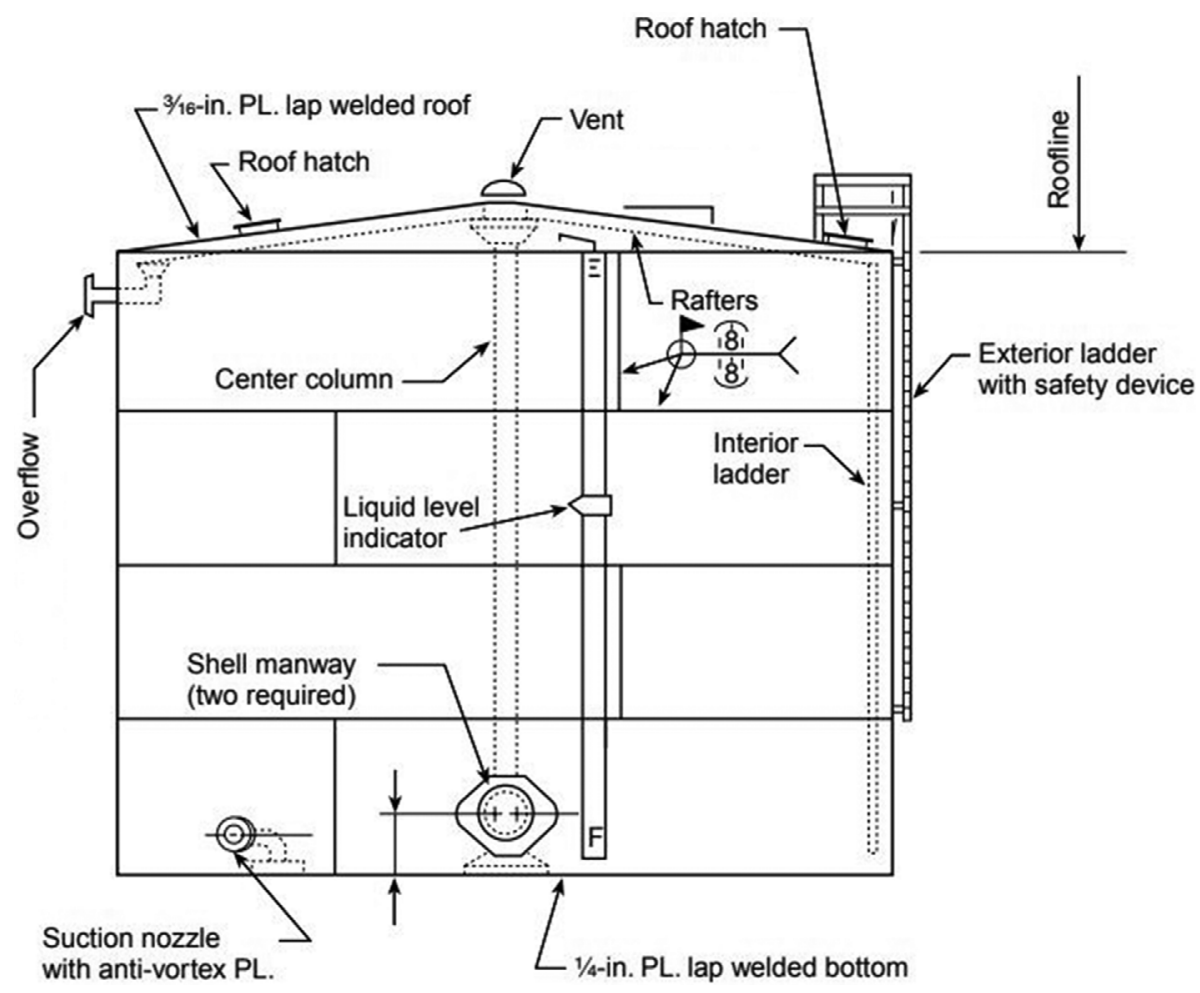

Fig. 2. Typical structure of the firewater tank [24]. 

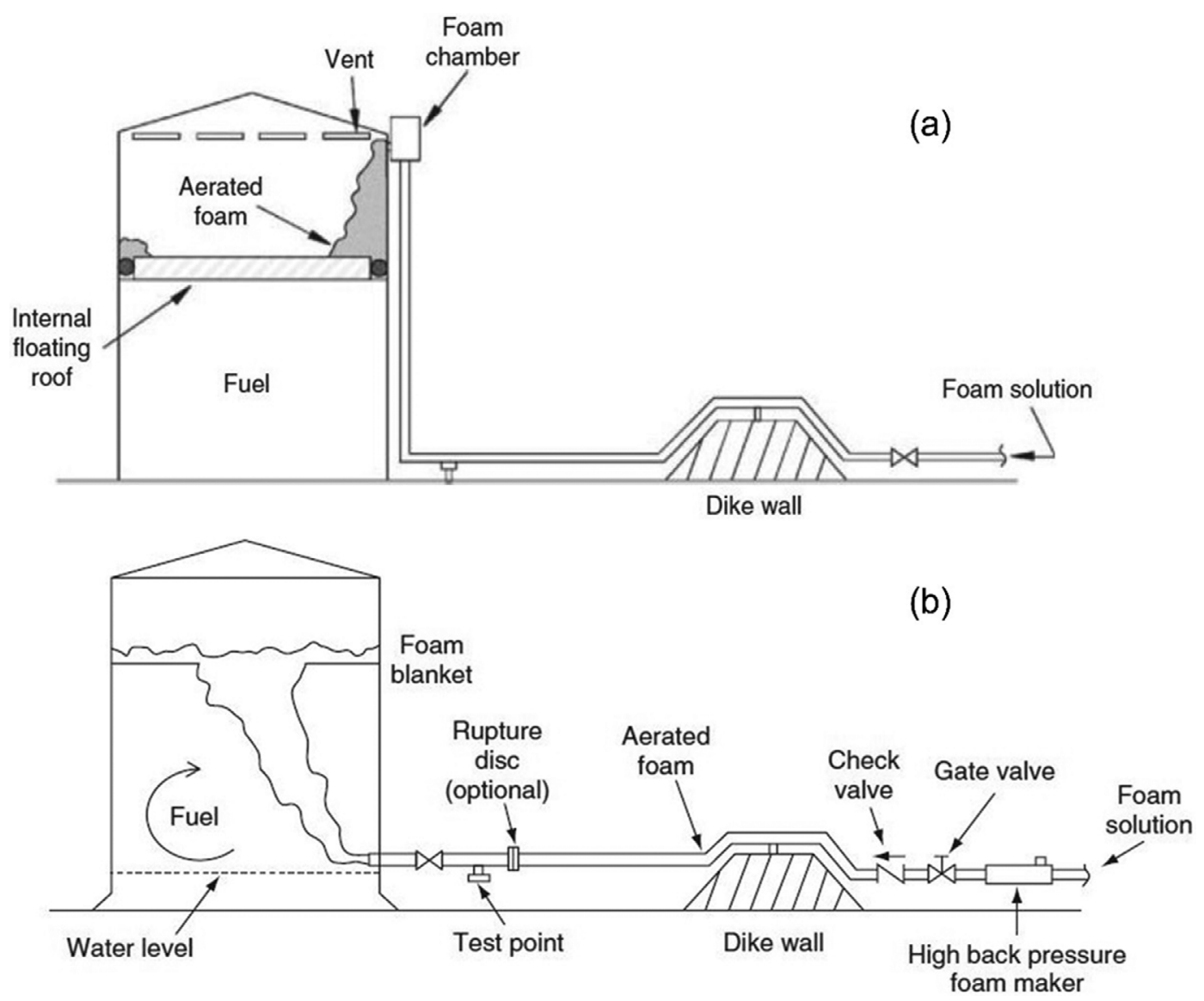

Fig. 3. Typical foam injection systems. (a) Topside foam application (b) sub-surface foam injection [25].

pourer calculations, and their application rates in case of fire-related emergencies are carefully calculated along with comprehensive parameter finalization, for the first time. The overall findings of the numerical design are also discussed and analyzed.

\section{MODEL LAYOUT}

Herein, a model layout is considered as shown in Fig. 1. The model layout is comprised of eight bulk petroleum storage tanks, four for gasoline storage, and four for diesel storage. The diameter and inter-tank distance of all these tanks are identical. All tanks are surrounded by a dike wall, firewater ring, foam network and access road. Firewater storage tanks are erected for bulk water storage for firefighting by using firewater pumps. The firewater storage tank is accompanied by a deep well pump for filling the firewater tank. The foam storage tank is installed to store foam concentrate.

Gasoline and diesel are among the most commonly used specialty petroleum products globally [20]. Gasoline is the most flammable liquid end-product of the petroleum refinery [21], while diesel is the most stable one [22]. Therefore, these two products are taken into account to design the firefighting system to a maximum broader scope. In real case scenarios, tanks are generally constructed in common dikes due to limited land spaces and cost issues [23]. Therefore, each category of tanks is surrounded by common diking. However, no different product storage tanks are placed in a single dike to prevent the mixing of products in case of tank overflow or boil-over. The radius and diameter of each tank are denoted by " $r$ " and " $D$ ", respectively. The complete firewater and foam network are installed underground except those areas where tanks and pumps are installed. The firefighting equipment such as master streams, firewater hydrants, etc. are installed on the main ring by small-sized branched piping coming above ground, while other associated facilities such as network section isolation valves are installed on the main ring piping aboveground by installing risers in the underground firewater network piping. Road ramps are constructed above dike walls to provide easy fire truck access inside tanks' dike in case of any emergency and/or for routine jobs. A typical structure of firewater tank is shown in Fig. 2 and typical foam injection systems are shown in Fig. 3.

\section{PETROLEUM CLASSIFICATION}

Flammable petroleum products are classified into three categories, concerning their physical properties: flash point, boiling point and Reid vapor pressure. However, the flashpoint is the most crucial factor considering the flammability of petroleum liquids [26,27]. This classification is shown in Fig. 4.

Based on the NFPA classification of petroleum products, the selected products in the model layout can be classified for further proceeding towards designing steps, as shown in Table 1. 


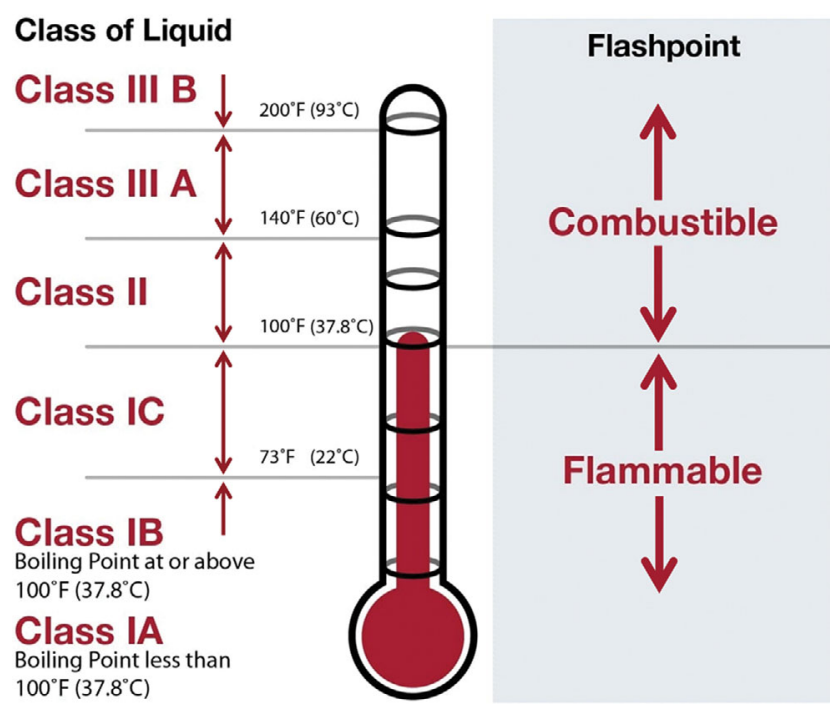

Fig. 4. NFPA classification of liquids.

\section{DESIGN}

The firefighting system of any bulk petroleum product storage facility is designed by considering different scenarios. The adequate amalgamation of selected scenarios into the design basis results in significant enhancement of safety system, making the storage facility safer and well prepared for any undesired forthcoming circumstances [28].

Three most commonly considered scenarios are typically taken into account for designing an efficient firefighting system: bulk petroleum product storage tank fire, truck loading and/or unloading gantry stations fire, and processing equipment such as vessel, pumps, cooler fire. However, the tank fire scenario is the most severe and worst-case scenario [29]. Hence, dominating the other two scenarios, thus selected for the design of the firefighting system.

The effectiveness of firefighting system can be ensured by considering the following aspects in the design basis:

a) Sufficient supply of firewater with adequate flow rate for cooling of the burning tank by using master streams and firewater hydrants, preventing flashback circumstances for an adequate period.

b) Sufficient supply of firewater with adequate flow rate for cooling of tanks around burning tank by using master streams and firewater hydrants, minimizing the excessive radiant heat coming from the adjacent tank on fire.

c) Adequate firewater pressure at all fire equipment installed at a distant location to overcome distant fire targets.

(d) Sufficient supply of foam for fire extinguishment for an adequate period.

(e) Sufficient amount of portable firefighting equipment placement at the site.

\section{Firewater Application on Tanks}

The design capacity of firefighting system installation at any petroleum handling and/or processing facility is calculated based on the assumption that "only one fire will occur at a time" [30]. This design concept can also be referred to as the "Single fire concept". Therefore, the numerical capacitive design calculations for any firefighting system design should be estimated by considering the largest single fire contingency to efficiently handle any fire emergency conditions. However, while designing such systems, it should be kept in mind that the firefighting system should have ample firewater storage capacity for cooling of the burning tank as well as the adjacent $\operatorname{tank}(\mathrm{s})$ continuously for a minimum time of six (06) hours [14]. Thus it is worth mentioning that you should not cool a tank on fire unless you can cool it evenly all around for $360^{\circ}$. Uneven cooling will allow the tank shell to fail in the area where the uneven cooling was applied.

1-1. Cooling of the Burning Tank Using Master Streams and Firewater Hydrants

The guidelines regarding the effective cooling of the burning tank are provided by the National Fire Protection Association (NFPA). The guidelines state that the burning vessel should be showered with firewater with the flow rate ranging between $6-20 \mathrm{~L} / \mathrm{min} / \mathrm{m}^{2}$ [27]. But the stated flow rate is specified for hydrocarbon processing vessels only, rather than bulk petroleum product storage tanks. However, the guidelines highlight the importance of cooling of the bulk petroleum product storage tanks by using firewater as it appreciably reduces the temperature of the tank surface in case of a tank fire scenario.

Oil and Gas Regulatory Authority (OGRA) provides sufficient necessary guidelines regarding the cooling of burning petroleum product storage tanks. The burning tank should be appreciably cooled by using master streams and firewater hydrants. The firewater application rate should be $10 \mathrm{~L} / \mathrm{min} / \mathrm{m}^{2}$ [15], irrespective of the tank roof type and the flammable petroleum product service,

Table 1. Credentials of the model tank farm

\begin{tabular}{cccccc}
\hline \hline Sr. No. & Tank name & $\begin{array}{c}\text { Flammable } \\
\text { product }\end{array}$ & $\begin{array}{c}\text { Flash point } \\
\left({ }^{\circ} \mathrm{F}\right)\end{array}$ & $\begin{array}{c}\text { Product } \\
\text { classification }\end{array}$ & Roof type \\
\hline 01 & Tank 01 & Gasoline & -43 & Class IB & Floating (internal) \\
02 & Tank 02 & Gasoline & -43 & Class IB & Floating (internal) \\
03 & Tank 03 & Gasoline & -43 & Class IB & Floating (internal) \\
04 & Tank 04 & Gasoline & -43 & Class IB & Floating (internal) \\
05 & Tank 05 & Diesel & 134 & Class II & Fixed (Cone type) \\
06 & Tank 06 & Diesel & 134 & Class II & Fixed (Cone type) \\
07 & Tank 07 & Diesel & 134 & Class II & Fixed (Cone type) \\
08 & Tank 08 & Diesel & 134 & Class II & Fixed (Cone type) \\
\hline
\end{tabular}


while the upper half portion of the burning tank shell should be considered for design calculations as follows:

The effective surface area of burning tank $=0.50 \times$ Surface area of tank's shell)

Firewater application requirement for burning tank $=($ Minimun application rate $) \times($ effective area $)$

1-2. Cooling of Adjacent Tanks Using Master Streams and Firewater Hydrants

The firefighting designer guidelines issued by NFPA do not mention the essential firewater application flowrates or the range of exposed surface areas of the bulk petroleum product storage tanks present adjacent to the burning tank to be cooled for minimizing the radiant heat originating from the burning tank. However, the guidelines highlight the importance of cooling of the bulk petroleum product storage tanks by using firewater, as the firewater application will appreciably reduce the temperature of the exposed surface area in case of a tank fire scenario [27].

The cooling of the adjacent tanks is considered one of the most important steps during the firefighting process in the case of tank fires. Single tank fires typically escalate into multiple tank fires due to the radiant heat, as shown in Fig. 5 and result in the bulk loss of property, manpower disturbance and adverse effects on the environment [23]. The numerical design calculations of the adjacent tank should consider the distances between the burning tank and the adjacent tanks, the direction of the wind, the exposed surface area of adjacent tanks to the radiant heat and the intensity of the flame.

NFPA and OGRA guide regards the spacing between the burning tank and the adjacent tanks. The bulk petroleum storage tank or any analogous erection residing within 30 meters or within the distance equal to one tank diameter from the burning tank shall require cooling. However, the greater value of the two aforementioned scenarios will be selected to enhance system efficiency. In addition to this, any tank residing within two tank diameters in the downwind direction to the burning tank will also require cool-

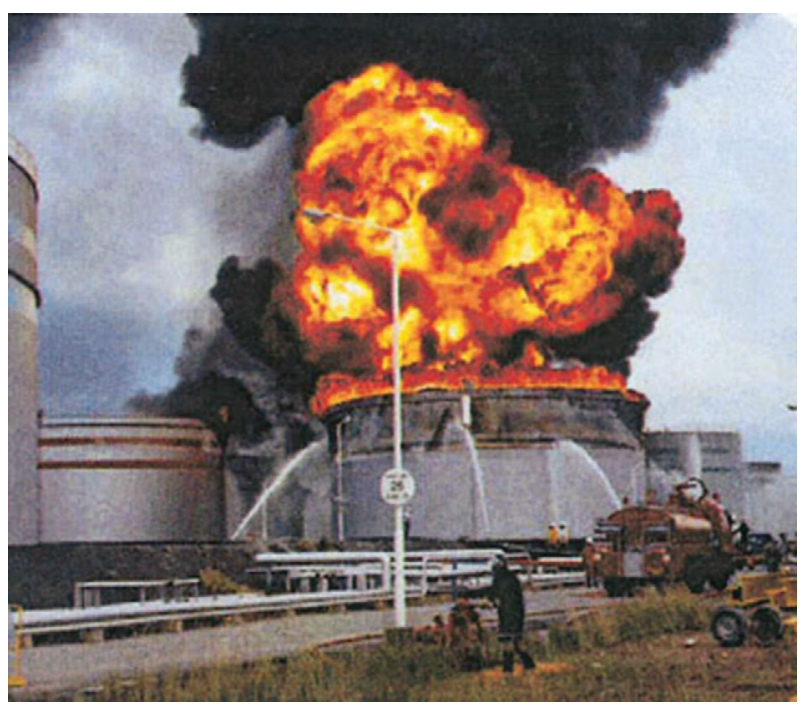

Fig. 5. Ignition of the second tank due to radiant heat [23]. ing. The cooling will be required only on the exposed side of the tank [15].

The adjacent tank should be appreciably cooled by using master streams and firewater hydrants. The firewater application rate should be $2 \mathrm{~L} / \mathrm{min} / \mathrm{m}^{2}$ [15], irrespective of the tank roof type and the flammable petroleum product service, while the effective surface area of the adjacent tank should be calculated by the following formula for design calculations:

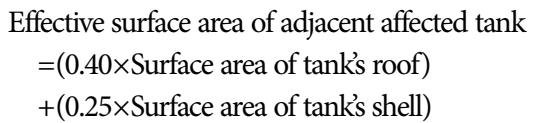

Surface area of tank's roof $=0.25 \pi \mathrm{D}^{2}$

Surface area of tank's shell $=\pi \mathrm{DH}$

where, $\mathrm{D}$ and $\mathrm{H}$ are the diameter and height of the burning tank, respectively.

\section{Firewater application rate for adjacent affected tank $=($ Mini. application rate $) \times($ effective area $)$}

1-3. Cooling of the Affected Tank Using Firewater Sprinkler Nozzles

Liquid petroleum product storage tanks are surrounded by dikes. However, in some cases, owing to limited land availability, the tanks with the same product service are placed in a single diked area during design stages [23]. The philosophy of common diking is advantageous concerning capital cost but this design philosophy results in the weakening of safety system integrity. While tanks are designed to be placed in a common dike, the space for fixed firefighting equipment installation around the dike is reduced. This design approach results in reducing the fire equipment per storage tank availability outside the dike. Moreover, the equipment is installed in shared or multipurpose. During a fire emergency, both the burning tank and adjacent affected tank(s) require firewater application [27]. The fire equipment that was installed considering the shared or multipurpose service can be operated only for a single tank at a time, resulting in the reduction of firewater flowrate application as per design calculations.

The tank farm cases where the firewater application equipment such as master streams and firewater hydrants are not available, or the number of equipment is less than that of the design capacity, alternative means of tank cooling by firewater spray nozzles is applied [31]. However, gasoline is more flammable compared to that of diesel fuels. Therefore, the installation of firewater spray nozzles is considered along with the installation of master streams and firewater hydrants. For designing a spray nozzle application system, a ring of firewater header is erected on the upper annular portion of the tank outside the tank shell [19]. The philosophy of installation is based on the generation of a thin film of firewater along the outer side of the tank shell to ensure the cooling of the tank against radiant heat. Literature shows that even a very thin firewater film is effective for the protection of storage tanks against thermal radiation [32]. However, above-all, master streams and firewater hydrants are a more reliable and effective source of cooling compared to firewater spray nozzles [33]. Therefore, master streams and firewater hydrants are given primary attention during firefighting system design. 
In tank fire scenarios, the tank(s) present in the surroundings of the burning tank are given sufficient importance along with the burning tank. The radiant heat from the burning has enough heat energy to ignite the product stored in the adjacent tank, as shown in Fig. 5. Therefore, special consideration is given to adjacent tank cooling during actual firefighting. It is a well-proven fact that a filled petroleum tank adjacent to a burning tank is less prone to ignite rather than the partially filled petroleum tank. The stored product present in the tank acts as a heat sink and prevents the rising of the shell temperature [23], hence contributing to the prevention of ignition. The firewater applied on the tank shell using firewater spray nozzles is very beneficial in reducing the temperature of those portions of the tank shell that are not in direct contact with the stored petroleum product.

API 2030 guides concern the designing of firewater sprinkler nozzles ring. The firewater sprinkler ring is generally erected to spray firewater only on the upper $3.7 \mathrm{~m}(12 \mathrm{ft})$ to $7.4 \mathrm{~m}(24 \mathrm{ft})$ of the tank's shell. The firewater application rate should be $4.1 \mathrm{~L} / \mathrm{min} /$ $\mathrm{m}^{2}$ on the surface being protected, irrespective of the tank's roof type and the flammable petroleum product service. The firewater application is required on the upper $25 \%$ of the tank's shell [31]. During the designing of the firewater sprinkler ring, the effective surface area of the tank is roughly assumed. Therefore, the upper $1 / 4^{\text {th }}$ portion of the tank should be taken for performing the design calculations as follows:

The effective surface area of adjacent affected tank $=(0.25 \times$ Surface area of tank's shell $)$

Firewater application requirement for burning tank $=($ Mini. application rate $) \times($ effective area $)$ $=4.1 \mathrm{~L} / \mathrm{min} / \mathrm{m}^{2} \times$ effective area

However, master streams and firewater hydrants are the most reliable means for cooling tanks.

\section{Firefighting Foam Requirement for Burning Tank}

The guidelines provided by NFPA and OGRA provide briefing regarding the effectiveness of firefighting foam usage for extinguishment of surface fires in bulk petroleum product storage tanks. The installation of the foam solution application system on atmospheric bulk quantity liquid petroleum product storage tanks has two primary objectives: suppression of vapors in case of excessive vapor generation, and the extinguishment of fire by forming a blanket over the surface of flammable liquid to cut the oxygen supply, consequently breaking the fire triangle [25]. The former issue gener- ally occurs with floating roof tanks, in which there is a possibility of vapor accumulation above the floating roof causing, excessive generation of flammable vapor clouds. However, the foam water solution also contributes towards minor lowering of the temperature of the top surface of the burning flammable liquid.

As per SFPE, aqueous film-forming foam (AFFF) is the most suitable option for the selection of firefighting foam concentrate, given its high fluidity along with superlative fire extinguishment characteristic [34]. The application of AFFF on the surface of the affected tank results in the generation of thin-film (also referred to as foam blanket), which prevents the availability of oxygen (present in ambient air) to the flammable product surface acting as a barrier, breaking the fire triangle, extinguishing the fire [34]. The AFFF has also sufficient capability of suppressing the generation of vapors to prevent vapor cloud formation.

Moreover, both international and national standards mention the desired values for foam (water) solution application rates as well as minimum foam inventory discharge time. However, the application of foam solution via foam pourers is the most applicable and recommended design practice. These foam pourers are sometimes also referred to as foam discharge outlets [36]. As per the guidelines of the aforementioned standards, the adequate number of foam discharge outlets required for effective fire extinguishment by gently pouring of foam solution depends on the diameter of the storage tank. The increase in the diameter of the tank results in increased tank storage capacity and hence a greater number of foam discharge outlets will be required. The required number of foam discharge outlets versus tank diameter is illustrated in Table 2. There are two types of tanks generally used for finished liquid petroleum product storage, fixed roof tank and floating roof tanks. 2-1. Fixed Roof Tanks

Fixed roof tanks are the most commonly used for the storage of kerosene, aviation fuels, diesel fuels, etc. [37]. In the case of fixed roof tanks, NFPA and OGRA define the foam water solution application rate of $4.1 \mathrm{~L} / \mathrm{min} / \mathrm{m}^{2}[14,35]$. However, the minimum foam inventory discharge time is variable for different liquid petroleum products, depending upon the flashpoint of these liquids as shown in Table 3.

\section{2-2. Floating Roof Tanks}

Floating (internal) roof tanks are the most commonly used type for the storage of Class I liquids [37]. There are generally two types of top surface fires expected in floating roof tanks, the rim seal area tank fire and the full surface tank fire [38]. The floating roof tanks are equipped with a movable seal along the annular portion

Table 2. Number of foam discharge outlets versus tank diameter

\begin{tabular}{clcc}
\hline \hline Sr. No. & \multicolumn{2}{c}{ Tank diameter } & $\begin{array}{c}\text { Minimum foam } \\
\text { discharge outlets }\end{array}$ \\
\cline { 2 - 4 } & \multicolumn{1}{c}{ Meters $(\mathrm{m})$} & Feet $(\mathrm{ft})$ & 6 \\
01 & Between 60 to 54 & Between 200 to 180 & 5 \\
03 & Between 54 to 48 & Between 180 to 160 & 4 \\
04 & Between 48 to 42 & Between 140 to 120 & 3 \\
05 & Between 42 to 36 & Between 120 to 80 & 2 \\
06 & Between 36 to 24 & Below 80 & 1 \\
\hline
\end{tabular}


Table 3. Foam solution application rate and minimum inventory discharge time

\begin{tabular}{|c|c|c|c|c|}
\hline \multirow{2}{*}{ Sr. No } & \multirow{2}{*}{ Hydrocarbon type } & \multicolumn{2}{|c|}{ Minimum application rate } & \multirow{2}{*}{$\begin{array}{l}\text { Minimum foam discharge } \\
\text { time ( } \mathrm{min})\end{array}$} \\
\hline & & $\mathrm{L} / \mathrm{min} / \mathrm{m}^{2}$ & $\mathrm{gpm} / \mathrm{ft}^{2}$ & \\
\hline 01 & $\begin{array}{l}\text { Hydrocarbons necessitating alcohol resistant } \\
\text { foams }\end{array}$ & \multicolumn{2}{|c|}{ As per foam manufacturer recommendations } & 55 \\
\hline 02 & Crude petroleum & 4.1 & 0.10 & 55 \\
\hline 03 & $\begin{array}{l}\text { Flashpoint under } 37.8^{\circ} \mathrm{C}\left(100^{\circ} \mathrm{F}\right) \text { or liquids } \\
\text { at temperatures exceeding their flash points }\end{array}$ & 4.1 & 0.10 & 55 \\
\hline 04 & $\begin{array}{l}\text { Flashpoint between } 37.8^{\circ} \mathrm{C}\left(100^{\circ} \mathrm{F}\right) \text { and } \\
93.3^{\circ} \mathrm{C}\left(140^{\circ} \mathrm{F}\right)\end{array}$ & 4.1 & 0.10 & 30 \\
\hline
\end{tabular}

of the tank for suppressing the vapors generation along with the smooth movement of the floating roof. There are numerous types of seals available in the market, such as mechanical shoe seal, partially or fully combustible seal, tube-type seal with a metallic weather shield and fully metallic secondary seal [36]. The guidelines regarding both tank fire scenarios are as follows:

\section{Rim seal tank fire}

In the case of rim seal fire on floating roof tanks, NFPA and OGRA define the foam water solution application rate of $12.2 \mathrm{~L} / \mathrm{min} / \mathrm{m}^{2}$ and the minimum foam inventory discharge time should be not less than 20 minutes $[15,36]$. The surface area of the rim seal can be calculated using the formula:

$$
\text { Surface area of rim seal }=0.25 \mathrm{D}^{2}-\left[0.25(\mathrm{D}-2 \mathrm{~s})^{2}\right]
$$

where, D and s are the tank diameter and the seal size of the burning tank, respectively.

\section{Full surface tank fire}

In case of full surface tank fire on internal floating roof tanks, NFPA and OGRA state that the tanks shall be well-thought-out to equivalent to that of fixed cone roof tank and foam system design philosophy will be based on the guidelines tabulated in Table 3 .

The total required foam quantity for both of the abovementioned scenarios shall be calculated by the addition of both primary and supplementary foam requirements. The primary foam requirement is the foam required to extinguish tank fire by pouring through foam discharge outlets, while the supplementary foam is the foam required for extinguishment of small fires such as bund fire by using portable hose lines.

Primary Foam Requirement $=$ Seal Area $\times$ Application rate
$\times$ Discharge time $\times$ Concentration

upplementary Foam Requirement=No. of hose-lines $\times 189$ LPM $\times$ Discharge time $\times$ Concentration$$
\text { Total Foam Required=Primary+Supplementary }
$$

\section{ANALYSIS}

The design of the firefighting system of any bulk petroleum product storage facility can be evaluated by considering different fire scenarios under consideration. The adequate amalgamation of

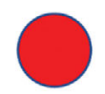

Burning $\operatorname{tank}(\mathrm{s})$

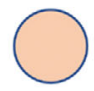

Effected $\operatorname{tank}(\mathrm{s})$

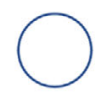

Remaining $\operatorname{tank}(s)$

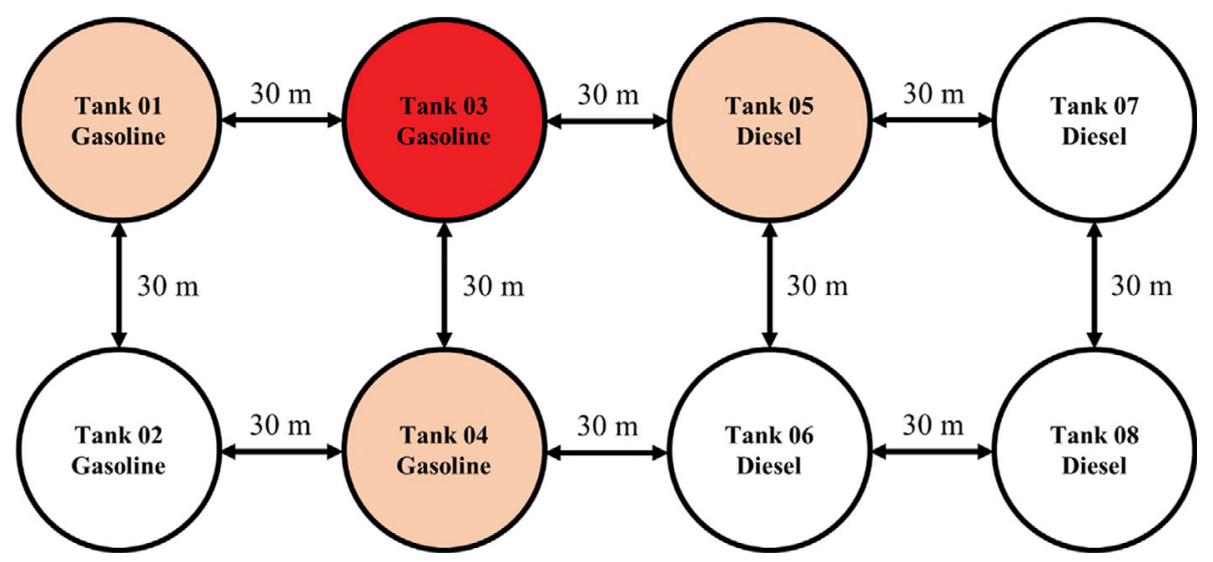

Fig. 6. Dimensional layout of the tank farm. 
selected scenarios into the design basis consequents in significant enhancement of safety system making the storage facility safer and well prepared for any undesired forthcoming circumstances. Therefore, the possible worst-case scenario should be selected for calculating the firefighting system's numerical design values.

The dimensional layout of the model tank farm is depicted in Fig. 6. The diameter and height of tanks are considered identical and are roughly taken as 40 meters and 12 meters, respectively, for proceeding towards further design calculation steps. The distance between each tank is 30 meters. Therefore, the distances between all parallel erected tanks are less than one diameter length of the burning petroleum product tank. Hence, all perpendicular adjacent tanks will require cooling in case of fire on any tank.

In Fig. 6, the scenario illustrates that fire has erupted on a Gasoline Tank. Therefore, Gasoline Tank (Tank \# 03) is taken as a burning tank and Gasoline Tank (Tank \# 01), Gasoline Tank (Tank \# 04) and Diesel Tank (Tank \# 05) are the adjacent affected tanks. Hence, firewater application along with foam solution application will be required on Gasoline Tank (Tank \# 03) for fire extinguishment, and firewater application is required only on Gasoline Tank (Tank \# 01), Gasoline Tank (Tank \# 04) and Diesel Tank (Tank \# 05) for cooling purpose.

1. Firewater Requirements for Cooling of the Burning Tank Using Master Streams and Firewater Hydrants

The firewater flowrate required for the cooling of the burning tank (Tank \# 03) can be calculated as follows:

From Eq. (5):

Surface area of tank's shell $=1,256 \mathrm{~m}^{2}$

The effective surface area of the burning can be calculated by using Eq. (1).

Effective surface area $=(0.50 \times$ Surface area of tank's shell $)$ $=\left(0.50 \times 1,256 \mathrm{~m}^{2}\right)=628 \mathrm{~m}^{2}$

The firewater application rate requirement for cooling of the burning tank can be calculated by using Eq. (2).

Firewater application rate for burning tank

$=($ Mini. application rate $) \times($ effective area $)$

$$
=\left(10 \mathrm{~L} / \mathrm{min} / \mathrm{m}^{2}\right) \times\left(628 \mathrm{~m}^{2}\right)=6,280 \mathrm{~L} / \mathrm{min}\left(377 \mathrm{~m}^{3} / \mathrm{h}\right)
$$

Firewater quantity (six hours basis) $=($ application rate $) \times($ time $)$ $=\left(377 \mathrm{~m}^{3} / \mathrm{h}\right) \times(6 \mathrm{~h})=\left(2,262 \mathrm{~m}^{3}\right)$

2. Firewater Requirements for Cooling of Adjacent Affected Tanks Using Master Streams and Firewater Hydrants

The firewater flowrate required for the cooling of the adjacent affected tank (Tank \# 01) can be calculated as follows:

From Eq. (5):

Surface area of tank's shell $=1,256 \mathrm{~m}^{2}$

From Eq. (4):

Surface area of tank's roof $=1,256 \mathrm{~m}^{2}$

The effective surface area of the adjacent affected tank can be calculated by using Eq. (3).

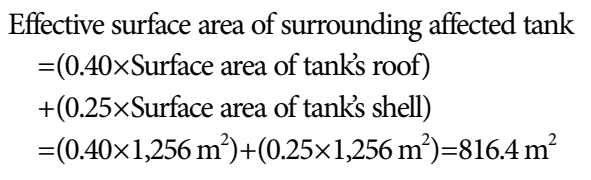

The firewater application rate requirement for cooling of burning tank can be calculated by using Eq. (2).

Firewater application rate for burning tank
$\quad=($ Minimum application rate $) \times($ effective area $)$
$\quad=\left(2 \frac{\mathrm{L}}{\mathrm{min} \mathrm{m}^{2}}\right) \times\left(816.4 \mathrm{~m}^{2}\right)=1,633 \frac{\mathrm{L}}{\mathrm{min}}=98 \frac{\mathrm{m}^{3}}{\mathrm{~h}}$

Firewater quantity (six hours basis)

$=($ application rate $) \times($ time $)=\left(98 \mathrm{~m}^{3} / \mathrm{h}\right) \times(6 \mathrm{hr})=588 \mathrm{~m}^{3}$

As the height and diameter of Tank \# 01, Tank \# 04 and Tank \# 05 are identical; therefore, the firewater application requirements for these tanks will be similar to that of Tank \# 01 .

The firewater requirements for cooling of all (both burning and adjacent affected tanks) are tabulated in Table 4.

3. Firewater Requirement for Cooling Using Firewater Sprinkler Nozzles

The firewater flowrate required for the cooling of adjacent affected

Table 4. Firewater application requirements for cooling of tanks using master streams and firewater hydrants

\begin{tabular}{|c|c|c|c|c|c|}
\hline \multirow{3}{*}{ Description } & \multirow{3}{*}{ Unit } & \multicolumn{4}{|c|}{ Firewater application requirement } \\
\hline & & \multirow{2}{*}{$\begin{array}{c}\text { For burning tank } \\
\text { Tank\# } 03\end{array}$} & \multicolumn{3}{|c|}{ For surrounding affected tanks } \\
\hline & & & Tank\# 01 & Tank\# 04 & Tank\# 05 \\
\hline Height & $\mathrm{m}$ & 10 & 10 & 10 & 10 \\
\hline Diameter & $\mathrm{m}$ & 40 & 40 & 40 & 40 \\
\hline Shell Area & $\mathrm{m}^{2}$ & 1,256 & 1,256 & 1,256 & 1,256 \\
\hline Roof Area & $\mathrm{m}^{2}$ & 1,256 & 1,256 & 1,256 & 1,256 \\
\hline Effective Area & $\mathrm{m}^{2}$ & 628 & 816.4 & 816.4 & 816.4 \\
\hline Mini. application rate recommendation & $\mathrm{L} / \mathrm{min} / \mathrm{m}^{2}$ & 10 & 2.0 & 2.0 & 2.0 \\
\hline Firewater application rate & $\mathrm{L} / \mathrm{min}$ & 6,280 & 1,633 & 1,633 & 1,633 \\
\hline Firewater application rate & $\mathrm{m}^{3} / \mathrm{h}$ & 377 & 98 & 98 & 98 \\
\hline Mini. Application time & $\mathrm{h}$ & 06 & 06 & 06 & 06 \\
\hline Firewater quantity required & $\mathrm{m}^{3}$ & 2,262 & 588 & 588 & 588 \\
\hline
\end{tabular}


tank (Tank \# 01) using sprinkler nozzles can be calculated as follows:

From Eq. (5):

Surface area of tank's shell $=1,256 \mathrm{~m}^{2}$

The effective surface area of the adjacent affected tank can be calculated by using Eq. (6):

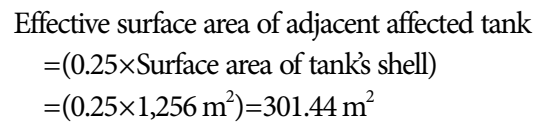

Firewater application requirement for affected tank $=($ Minimum application rate $) \times($ effective area $)$ $=4.1 \mathrm{~L} / \mathrm{min} / \mathrm{m}^{2} \times 301.44 \mathrm{~m}^{2}=1,236 \mathrm{~L} / \mathrm{min}\left(74 \mathrm{~m}^{3} / \mathrm{h}\right) \mathrm{m}^{2}$

Firewater quantity (six hours basis) $=($ application rate $) \times($ time $)=\left(74 \mathrm{~m}^{3} / \mathrm{h}\right) \times(6 \mathrm{~h})=444 \mathrm{~m}^{3}$

Besides firewater quantity, the number of nozzles to be installed on each firewater sprinkler ring can be calculated as follows:

Circumference of $\operatorname{tank}=\pi \mathrm{D}=125.6 \mathrm{~m}$

The surface area covered by a single sprinkler nozzle is crucial in calculating the total number of required nozzles. As per NFPA recommendations, sprinkler spacing shall not exceed $9.3 \mathrm{~m}^{2}\left(100 \mathrm{ft}^{2}\right)$ per sprinkler or exceed $3.7 \mathrm{~m}$ (12 ft) spacing between sprinklers [33]. Selecting the nozzle spacing of 2.5 meters, the number of sprinkler nozzles required for effective coverage of the whole circumference of the tank's shell will be calculated as follows:

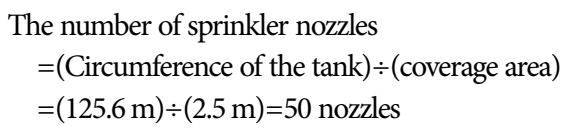

The firewater requirements for cooling of all adjacent affected tanks are tabulated in Table 5.

\section{Firefighting Foam Calculations for Burning Tanks}

Firefighting foam is required for both primary and supplementary purposes, such as the real-time production of foam solution for application on flammable liquid surface using foam pourers for the extinguishment of tank fire and the real-time production of foam solution for application on flammable liquid spills using por- table hose lines for the extinguishment of bund fire, respectively [39]. In addition to fire extinguishment, foam solution can be applied on small oil spills for vapor suppression. The calculations of firefighting foam can be performed considering two type of fire scenarios.

4-1. Rim Seal Tank Fire Scenario

In case of rim seal fire on floating roof tanks, the foam water solution application rate of $12.2 \mathrm{~L} / \mathrm{min} / \mathrm{m}^{2}$ and discharge time should be taken as 20 minutes [36]. The surface area of the rim seal can be calculated using Eq. (8):

Surface area of rim seal $=0.25 \mathrm{D}^{2}-\left[0.25(\mathrm{D}-2 \mathrm{~s})^{2}\right]$

The nominal seal sizes recommended for calculations by Chevron Texaco Engineering Practices are 6 and 8 inches for internal floating roof tanks. Therefore, considering the seal size (s) equivalent to 8 inches $(0.2 \mathrm{~m})$ as the possible worst-case scenario, the surface area of the rim seal will be:

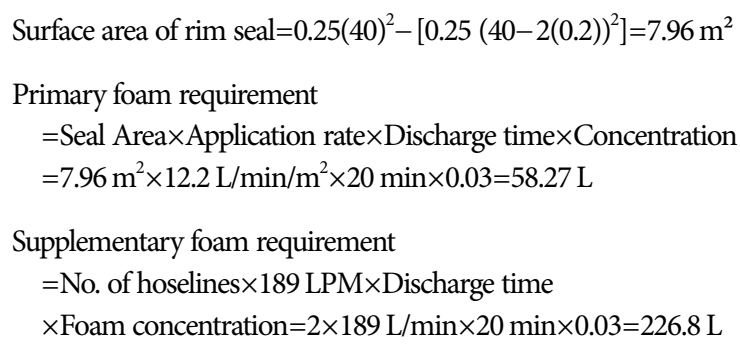

Supplementary foam requirement

$=$ No. of hoselines $\times 189 \mathrm{LPM} \times$ Discharge time

$\times$ Foam concentration $=2 \times 189 \mathrm{~L} / \mathrm{min} \times 20 \mathrm{~min} \times 0.03=226.8 \mathrm{~L}$

Total foam required $=$ Primary + Supplementary

$=58.27 \mathrm{~L}+226.8 \mathrm{~L}=285 \mathrm{~L}\left(0.28 \mathrm{~m}^{3}\right)$

Total firewater required for foam production $=285 \mathrm{~L} \times 100 \div 3=9,500 \mathrm{~L}\left(9.5 \mathrm{~m}^{3}\right)$

Total foam solution ( $97 \%$ water $+3 \%$ foam) $=285 \mathrm{~L}\left(0.3 \mathrm{~m}^{3}\right)+9,500 \mathrm{~L}\left(9.5 \mathrm{~m}^{3}\right)=9,785\left(9.8 \mathrm{~m}^{3}\right)$

\section{4-2. Full Surface Tank Fire}

A full surface tank fire is one of the possible scenarios in floating tanks. When a fire erupts on a bulk flammable petroleum storage tank internal floating roof's seal, the fire escalates and propagates forming a full surface tank fire, if the adequate emergency response steps are not adequately followed by firefighters [23]. In most cases,

Table 5. Firewater application requirements for cooling of adjacent tanks using the sprinkler system

\begin{tabular}{lcccc}
\hline \multirow{2}{*}{ Description } & Unit & \multicolumn{2}{c}{ Firewater application requirement for surrounding the affected tanks } \\
\cline { 3 - 5 } & & Tank\# 01 & Tank\# 04 & Tank\# 05 \\
\hline Height & $\mathrm{m}$ & 10 & 10 & 10 \\
Diameter & $\mathrm{m}$ & 40 & 40 & 40 \\
Shell area & $\mathrm{m}^{2}$ & 1,256 & 1,256 & 1,256 \\
Effective area & $\mathrm{m}^{2}$ & 301.44 & 301.44 & 301.44 \\
Mini. application rate recommendation & $\mathrm{L} / \mathrm{min}^{2} \mathrm{~m}^{2}$ & 4.1 & 4.1 & 4.1 \\
Firewater application rate & $\mathrm{L} / \mathrm{min}$ & 1,236 & 1,236 & 1,236 \\
Firewater application rate & $\mathrm{m}^{3} / \mathrm{h}$ & 74 & 74 & 74 \\
Mini. Application time & $\mathrm{h}$ & 06 & 06 & 06 \\
Firewater quantity required & $\mathrm{m}$ & 444 & 444 & 444 \\
Number of nozzles require on each ring & Each & 50 & 50 & 50 \\
\hline
\end{tabular}


Table 6. Foam water solution application requirements for extinguishment of tank fire

\begin{tabular}{|c|c|c|c|}
\hline \multirow{2}{*}{ Description } & \multirow{2}{*}{ Unit } & \multicolumn{2}{|c|}{ Fire on Tank \# 03} \\
\hline & & Rim seal area fire & Full surface tank fire \\
\hline Height & $\mathrm{m}$ & 10 & 10 \\
\hline Diameter & $\mathrm{m}$ & 40 & 40 \\
\hline Surface area & $\mathrm{m}^{2}$ & 7.96 & 1,256 \\
\hline Mini. application rate recommendation & $\mathrm{L} / \mathrm{min} / \mathrm{m}^{2}$ & 12.2 & 4.1 \\
\hline Mini. application time & Min & 20 & 55 \\
\hline Foam flowrate & $\mathrm{m}^{3} / \mathrm{h}$ & 0.84 & 9.93 \\
\hline Firewater flowrate & $\mathrm{m}^{3} / \mathrm{h}$ & 28.5 & 332 \\
\hline Foam water solution flowrate & $\mathrm{m}^{3} / \mathrm{h}$ & 29.4 & 341.5 \\
\hline Foam required $3 \%$ & $\mathrm{~m}^{3}$ & 0.28 & 9.1 \\
\hline Firewater required 97\% & $\mathrm{m}^{3}$ & 9.5 & 304 \\
\hline Foam water solution required & $\mathrm{m}^{3}$ & 9.8 & 313 \\
\hline Number of foam pourers required & Each & 03 & 03 \\
\hline
\end{tabular}

adequate and timely steps are taken, but still the rim seal fire converts into a full surface tank fire igniting the adjacent tanks and so on. Therefore, the facility should be ready for meeting any kind of emergency scenario.

In case of a full surface tank fire on internal floating roof tanks, NFPA and OGRA state that the tanks shall be well-thought-out to be equivalent to that of fixed cone roof tank, and foam system design philosophy will be based on the guidelines tabulated in Table 3 .

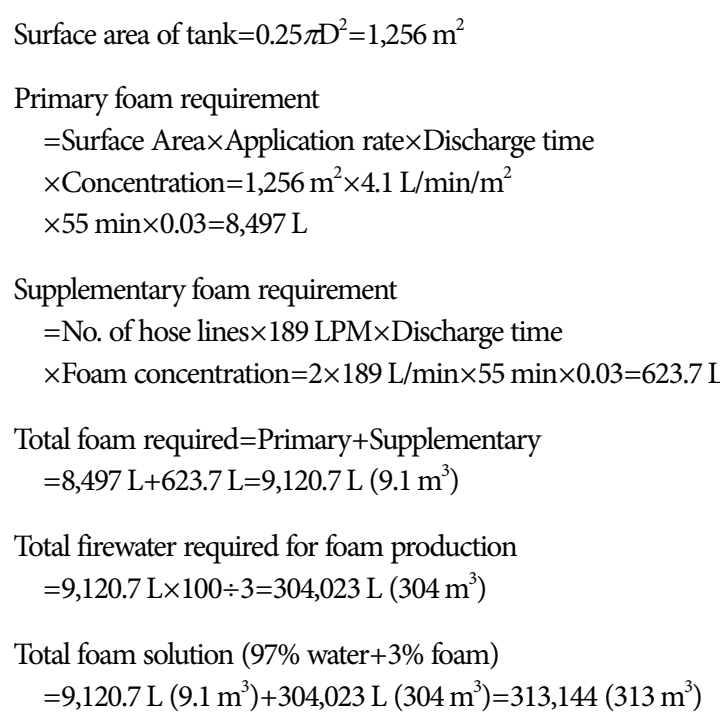

\section{4-3. Reserved Storage of Foam}

The quantity of foam identical to that of calculated value should be stored as standby in addition to the foam stored in field vessel skid ready to operate in order to setback the system into original place after foam operation. The reserved foam can be stored into separate vessels, separate chambers of the common vessel, foam storage drums or can, but within the site premises. However, foam can be procured or borrowed with 24 hours from another approved source available nearby [14].

4-4. Foam Pourers

The number of foam pourers should be installed in compliance with international standard recommendations and the cumulative foam solution flowrate should meet the minimum foam application rate demand. However, the requirement of foam is higher in the case of a full surface tank fire scenario. Therefore, the foam pourers will be selected based on full surface tank fire calculations.

The required flow rate for the gentle pouring of foam water solution through foam discharge outlets can be calculated as follows:

Foam pouring flowrate required $=$ Surface Area $\times$ Application rate $=1,256 \mathrm{~m}^{2} \times 4.1 \mathrm{~L} / \mathrm{min} / \mathrm{m}^{2}=5,150 \mathrm{~L} / \mathrm{min}$

Number of foam pourer required $(40 \mathrm{~m}$ dia. $\tan \mathrm{k})=03 \quad *$ Table 2

Flowrate of single foam discharge outlet $=1,717 \mathrm{~L} / \mathrm{min}$

Foam solution requirements for the extinguishment of tank fire are tabulated in Table 6 .

\section{Firewater Pumps}

The efficient and accurate design of the firefighting system is mandatory for ensuring the integrity of the overall emergency preparedness of any petroleum handling or processing facility. The total firewater water flowrate, firewater storage requirement and foam storage requirement should be estimated considering worstcase scenarios.

$$
\begin{aligned}
& \text { Total firewater flowrate requirement } \\
& \text { =Firewater required for cooling of burning tank } \\
& \text { +Firewater required for cooling of the adjacent tank(s) } \\
& \text { +Firewater required for foam solution production } \\
& =377 \frac{\mathrm{m}^{3}}{\mathrm{~h}}+\left(98 \frac{\mathrm{m}^{3}}{\mathrm{~h}}+98 \frac{\mathrm{m}^{3}}{\mathrm{~h}}+98 \frac{\mathrm{m}^{3}}{\mathrm{~h}}\right)+332 \frac{\mathrm{m}^{3}}{\mathrm{~h}}=1,003 \frac{\mathrm{m}^{3}}{\mathrm{~h}}
\end{aligned}
$$

Therefore, two motor-driven firewater pumps with a cumulative flow rate of $1,003 \mathrm{~m}^{3} / \mathrm{h}$ and one engine-driven firewater pump with a flow rate of $1,003 \mathrm{~m}^{3} / \mathrm{h}$ will be installed. However, two enginedriven firewater pumps with a cumulative flow rate of $1,003 \mathrm{~m}^{3} / \mathrm{h}$ can also be considered for installation based on authorities having jurisdiction decision. The discharge pressure of all firewater pumps should not be less than 10 bar to maintain header pressure of 7 bar in the firewater network header based on the worst-case scenario. Moreover, a firewater jockey pump with $30 \mathrm{~m}^{3} / \mathrm{h}$ will be more than 
enough for maintaining header pressure in routine conditions. All firewater pumps will be connected in parallel sequence with the discharge pressure of $10 \mathrm{bar}$ (150 psig) [25].

\section{Firewater Distribution Network}

Besides adequate firewater flowrate, the firewater network's main header pipe sizing is one of the crucial factors in the designing of the overall firefighting system. The header sizing can be calculated by using general fluid flow rules for calculating nominal pipe sizing for non-viscous flow [40]:

Diameter of firewater header $=(\mathrm{Q} \div 1.2)^{1 / 3}-2$ for $\mathrm{Q}(\mathrm{GPM})>100$

Diameter of firewater header $=0.25(\mathrm{Q})^{1 / 2} \quad$ for $\mathrm{Q}(\mathrm{GPM}) \leq 100$

The demanded firewater flowrate is $1,003 \mathrm{~m}^{3} / \mathrm{h}(4,416 \mathrm{GPM})$, which far greater than 100 .

Therefore,

Diameter of firewater header $=(Q \div 1.2)^{1 / 3}-2=13.44$ inches

However, standard pipe sizing of $13 \frac{1}{2}$ " is not manufactured by any pipe material supplier. Therefore, 14 " dia. firewater header will be laid considering the nature of process liquid.

\section{Firewater Storage Tank}

Total firewater quantity requirement

=Firewater required for cooling of burning tank

+Firewater required for cooling of the adjacent $\operatorname{tank}(\mathrm{s})$

+ Firewater required for foam solution production

$=2,262 \mathrm{~m}^{3}+588 \mathrm{~m}^{3}+588 \mathrm{~m}^{3}+588 \mathrm{~m}^{3}+304 \mathrm{~m}^{3}=4,330 \mathrm{~m}^{3}$

The installation of a firewater tank with a nominal capacity of $4,330 \mathrm{~m}^{3}$ is required for the provision of adequate supply to the whole facility. It should be kept in mind that welded steel firewater tanks have dead stock of water at the bottom of the tank. Therefore, the system will not be able to withdraw this firewater into service, in any case, owing to the raised level of tank suction nozzles. In cone-type fixed roof tanks, when the tank is filled below the safe fill level but to a predetermined level, and the amount of firewater contained within the tank structure is just approaching to its safe-fill level, in compliance with the approved operating procedure, this capacity is termed as the normal capacity of the firewater tank [40]. Moreover, as per API 2350, the normal capacity of the firewater tank (cone-type fixed) will be taken as $90 \%$ of the maximum capacity, if the operating procedures are not available. The remaining $10 \%$ of the tank will be taken as non-usable volume. The nominal capacity can be calculated as follows:

$$
\text { Geometric volume }=1.10 \times 4,330 \mathrm{~m}^{3}=4,763 \mathrm{~m}^{3}
$$

Continuing with the consistency in the height of all tanks of the facility. Selecting the firewater tank's height equivalent to all other tanks. i.e., $10 \mathrm{~m}$. The diameter of the tank can be calculated as follows:

Volume $=$ Area of crosssection $\times$ Height $=0.25 \pi \mathrm{D}^{2} \mathrm{H}$

Diameter of firewater tank $=(\text { Volume } \div 0.25 \pi \mathrm{H})^{1 / 2}=24.63 \mathrm{~m}$

Moreover, there is quite a flexibility in the selection of the capacity of deep-well pump for suction of underground water to fill the firewater tank. However, it should be ensured that the level of firewater inside the firewater tank should be maintained more than twothirds of the nominal capacity every time to ensure the availability of excess firewater in case of an emergency.

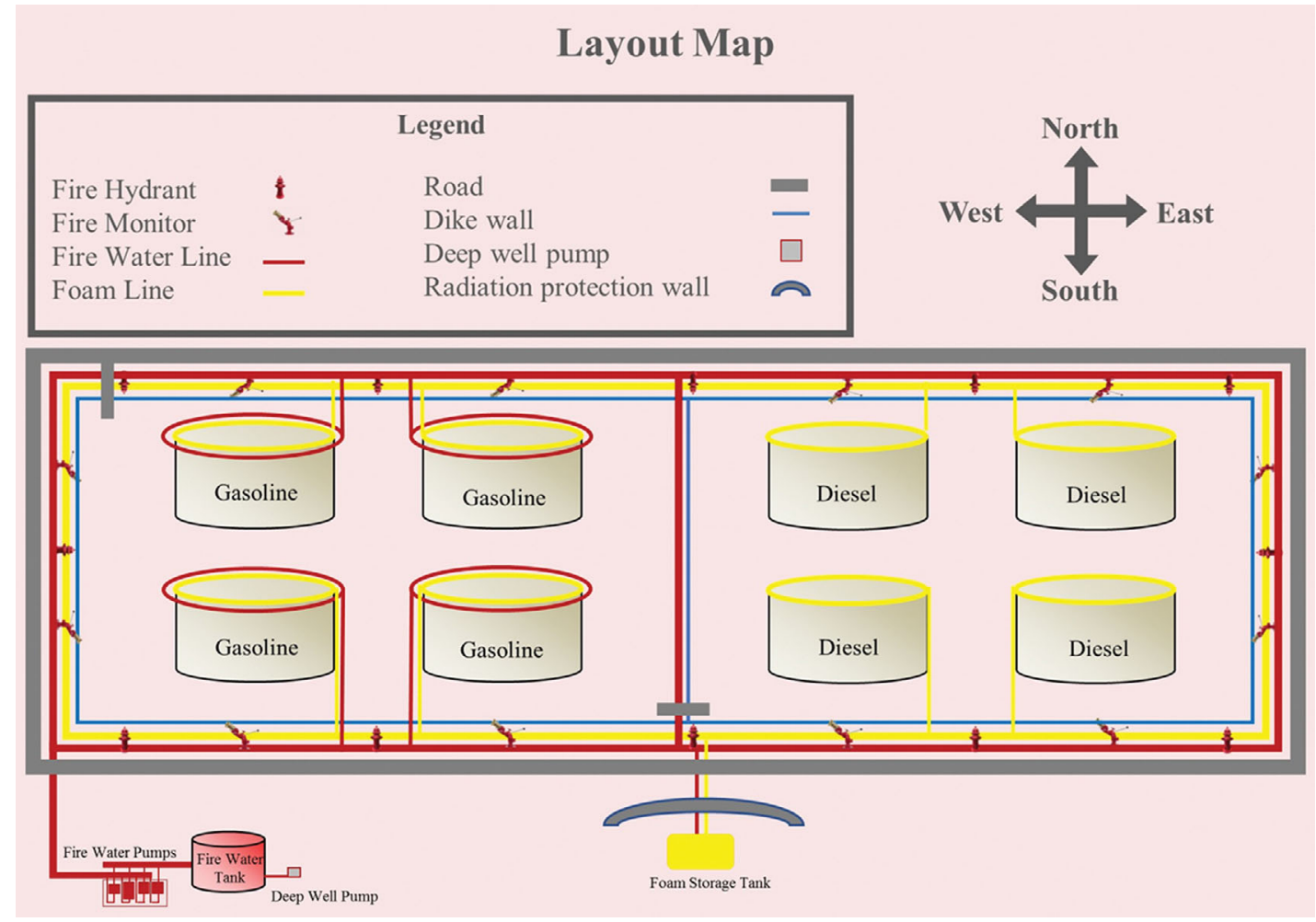

Fig. 7. Final design of the firefighting system. 
The overall findings of design and analysis are then incorporated into the model tank farm and depicted in Fig. 7.

\section{CONCLUSION}

Firefighting system design calculations were conducted for both firewater cooling and firefighting foam extinguishment systems. The calculations were employed for both the burning tank, considering the full surface tank fire and the rim seal area tank fire, and the cooling of the adjacent affected $\operatorname{tank}(\mathrm{s})$. The clarification regarding design accuracy and adequacy was verified by a complete firefighting system design on a model tank farm. Based on our comprehensive and in-depth design analysis, following installations are required for good preparedness of the facility for meeting any fire safety emergency:

1. Firewater tank with nominal firewater storage of $4,330 \mathrm{~m}^{3}$ (Height 10 m, Dia. 24.63 m).

2. Two (02) motor-driven firewater pumps of $501.5 \mathrm{~m}^{3} / \mathrm{h}(2,208$ GPM) capacity each.

3. One standby engine-driven firewater pumps of $1,003 \mathrm{~m}^{3} / \mathrm{h}$ (4,416 GPM) capacity.

4. One jockey firewater pump of $30 \mathrm{~m}^{3} / \mathrm{h}(132 \mathrm{GPM})$ capacity with power backup.

5. 14" dia. firewater header lying around dikes of all flammable product storage tanks.

6. One firewater sprinkler ring around every gasoline tank comprising 50 nozzles each.

7. Firewater equipment such as master streams and firewater hydrants around dikes of all flammable product storage tanks with a cumulative firewater discharge flow rate of not less than $377 \mathrm{~m}^{3}$ / h (1,659 GPM) for every tank.

8. Foam skid vessel with nominal foam storage of $9.1 \mathrm{~m}^{3}$.

9. Additional standby foam storage of $9.1 \mathrm{~m}^{3}$.

10. Three (03) foam discharge outlets on each flammable product storage tanks with cumulative foam water solution discharge flowrate not less than $341.5 \mathrm{~m}^{3} / \mathrm{h}$ (1,503 GPM).

We have presented this work as a detailed study of the formulation of industrial firefighting system designs. This comprehensive numerical design analysis offers a simple and wide-ranging guide to industrial practitioners to design or to verify the adequacy of the designed firefighting systems. Moreover, these numerical design formulations can be used to further develop numerical methods for continuous research and development in the field of fire safety design engineering.

\section{ACKNOWLDEGEMENTS}

The support from the National Research Foundation of Korea under the project (NRF-2020R1I1A1A01072793) is gratefully acknowldeged. Also, this work was supported by the National Research Foundation of Korea (2019R1A4A1027795) for Young-Kwon Park.

\section{REFERENCES}

1. M. Elhelw, A. El-Shobaky, A. Attia and W. M. El-Maghlany, Pro- cess Saf. Environ. Prot., 146, 670 (2021).

2. J. I. Chang and C.-C. Lin, J. Loss Prev. Process Ind., 19(1), 51 (2006).

3. H. Persson and A. Lönnermark, Tank fires-Review of fire incidents 1951-2003, Digitala Vetenskapliga Arkivet, Uppsala, Sweden (2004).

4. I. M. Shaluf and S. A. Abdullah, J. Loss Prev. Process Ind., 24, 1 (2011).

5. B. Zheng and G. H. Chen, Process Saf. Progr., 30(3), 29 (2011).

6. A. Dutta, D. Das, R. K. Jana and X. Vinh Vo, Resour. Policy, 69, 101816 (2020).

7. B. Oray Güngör, H. M. Ertuğrul and U. Soytaş, Technol. Forecas. and Social Change, 166, 120637 (2021).

8. B. Sun, K. Guo and V. K. Pareek, J. Loss Prev. Process Ind., 35, 200 (2015).

9. M. E. M. Soudagar, N. R. Banapurmath, A. Afzal, N. Hossain, M. M. Abbas, M. A. C. M. Haniffa, B. Naik, W. Ahmed, S. Nizamuddin and N. M. Mubarak, Sci. Rep., 10, 108 (2020).

10. H. Chowdhury, T. Chowdhury, N. Hossain, P. Chowdhury, B. Salam, S. M. Sait and T. M. I. Mahlia, Environ. Sci. Pollut. Res., 25, 12881 (2020).

11. H. Kim, J.-S. Koh, Y. Kim and T. G. Theofanous, Korean. J. Chem. Eng., 22, 8 (2005).

12. M. J. Hurley, SFPE handbook of fire protection engineering, Springer, New York (2015).

13. A. E. Cote, Fire protection handbook, 20th Edition, NFPA (2008).

14. API RP 2001: Standard for fire protection in refineries, $10^{\text {th }}$ Edition. (2012).

15. OGRA Technical Standards for the Petroleum Industry (Depots for the Storage of Petroleum Products) (2009).

16. IP19: Fire precautions at petroleum refineries and bulk storage installations (2012).

17. IPS-E-SF-220: Engineering Standard for Fire Water Distribution and Storage Facilities, Iranian Petroleum Ministry (1993).

18. Directorate, OISD, STD 116-Fire protection facilities for petroleum refineries and oil/gas processing plants, New Delhi: OISD (1999).

19. I. Alimohammadi, Iran J. Health Saf. Environ., 2(4), 385 (2015).

20. S. Parkash, Petroleum Fuels Manufacturing Handbook: including Specialty Products and Sustainable Manufacturing Techniques: including Specialty Products and Sustainable Manufacturing Techniques, McGraw Hill Professional (2009).

21. C. S. Hsu and P. R. Robinson, Gasoline production and blending, in Springer handbook of petroleum technology, Springer, Switzerland (2017).

22. A. M. Aitani, Encyclopedia of Energy, 4, 715 (2004).

23. T. V. Rodante, Process Saf. Progr., 24(2), 98 (2005).

24. NFPA 22: Standard for Water Tanks for Private Fire Protection (2018).

25. T. J. Martin, Fire-fighting foam technology. in foam engineering: Fundamentals and applications, John Wiley \& Sons, Inc., Chichester, West Sussex, U.K. (2012).

26. NFPA 30: Flammable and Combustible Liquids Code (2018).

27. NFPA 15: Standard for Water Spray Fixed Systems for Fire Protection (2017).

28. J. W. Lim, J. Loss Prev. Process Ind., 62, 103970 (2019).

29. J. Glatz, M. Gorzás and M. Hovanec, Oil tank fire modelling for the purposes of emergency planning, in Production Management and Engineering Sciences, ROUTLEDGE in association with GSE 
Research (2016).

30. I. Sutton, Plant design and operations, Oxford: Gulf Professional Publishing, Cambridge (2017).

31. API RP 2030: Application of fixed water spray systems for fire protection in the petroleum and petrochemical industries, 4th Edition (2014).

32. K. A. Mansour, Fires in large atmospheric storage tanks and their effect on adjacent tanks, $\mathrm{PhD}$ Thesis (2012).

33. NFPA 16: Standard for the Installation of Foam-Water Sprinkler and Foam-Water Spray Systems (2019).

34. J. L. Scheffey, Foam agents and AFFF system design considerations, in SFPE Handbook of Fire Protection Engineering, Springer, New
York (2016).

35. Q. Zhang, L. Wang, Y. Bi. D. Xu, H. Zhi and P. Qiu, J. Hazard. Mater., 287, 87 (2015).

36. NFPA 11: Standard for Low-, Medium-, and High-Expansion Foam (2019).

37. API 650: Welded steel tanks for oil storage, 13th Edition (2020).

38. F. P. Xu-qing, L. Quan-Zhen and G. Hong, Procedia Eng., 11, 189 (2011).

39. P. J. DiNenno, SFPE handbook of fire protection engineering, Society of Fire Protection Engineers, Bethesda (2008).

40. J. N. Adams, Chem. Eng. Prog., 93(12), 55 (1997). 